University for Business and Technology in Kosovo

UBT Knowledge Center

UBT International Conference

2018 UBT International Conference

Oct 27th, 3:15 PM - 4:45 PM

\title{
The Statistical Comparison of Remittances in Kosovo with Balkan Countries
}

\author{
Blerina Jashari \\ University for Business and Technology, blerina.jashari@ubt-uni.net \\ Mentor Geci \\ University for Business and Technology, mentor.geci@ubt-uni.net
}

Follow this and additional works at: https://knowledgecenter.ubt-uni.net/conference

Part of the Business Commons

\begin{abstract}
Recommended Citation
Jashari, Blerina and Geci, Mentor, "The Statistical Comparison of Remittances in Kosovo with Balkan Countries" (2018). UBT International Conference. 326.

https://knowledgecenter.ubt-uni.net/conference/2018/all-events/326
\end{abstract}

This Event is brought to you for free and open access by the Publication and Journals at UBT Knowledge Center. It has been accepted for inclusion in UBT International Conference by an authorized administrator of UBT Knowledge Center. For more information, please contact knowledge.center@ubt-uni.net. 


\title{
"The Statistical Comparison of Remittances in Kosovo with Balkan Countries" (The applications of statistical methods)
}

\author{
Blerina Jashari, Mentor Geci \\ UBT - Higher Education Institution, Lagjja Kalabria, 10000 p.n., Prishtine, \\ Kosovo \\ blerina.jashari@ubt-uni.net; bj34471@ubt-uni.net;
}

\begin{abstract}
Taking into account that Kosovo is a developing country, revenues coming from other countries play an important role. The paper will present a clear picture that examines the level of remittances in the country as well as external countries. In addition to the level of remittances, a literature review will also be made regarding the methodology used. Remittances received in Kosovo, which also represent the largest category within the secondary income account, amounted to euro 568.8 million in September 2015, representing an annual growth of 12.5 percent. One of the reasons why a remittance study is done is to identify more clearly how remittances affect notwithstanding the reports and publications made by the Kosovo Statistical Agency, the Central Bank of Kosovo, etc. It has been seen that there is still room for detailed analysis of statistics that would be even more useful to have a clearer picture of the interconnection that would affect the decision-making process. In addition to Kosovo, the research is also based on data released by the World Bank on remittances to other Balkan countries. Another purpose of the research is to compare remittances in Kosovo with those of the Balkan countries. Except for comparison, the link between them and their contribution to economic development in one country should be found.
\end{abstract}

Keywords: Remittances, Central Bank, Kosovo, Balkan Countries, Statistics, Economic Development.

\section{Introduction}

Appreciating the importance of this paper, comparisons of remittances in Kosovo with the Balkan countries will be made, to make statistical comparisons. We will apply some statistical methods such as regression, correlation and forecast models.Remittances are shipments paid by emigrants to the family left behind.One of the basic questions of this research is how do remittances change from country to country. How can remittances in Kosovo be different with those in Slovenia or any other Balkan country? As a next question we can assume how much the remittances put an effect to the growth or reduction of a country's Gross Domestic Product. The research questions represent a unique research in which there was plenty of room for applying the various statistical methods mentioned above.

Literature Review

In Kosovo, considering that it is a developing country, revenues from other countries play an important role in the economic development of the country. A high inflow of remittances also affect the inflationary pressure and expand the trade deficit. Economists of development have mentioned a lot of remittance consumption effects that may be as wide as 300 percent and which often favor rural communities. An empirical research provides support for remittances resulting 
in investment activities, though these investments are generated in real estate such as housing, land and small firms (Robertset al. 2008:23). Since remittances are only transferred to part of the wealth of the population, there may be some inequality. Theoretical studies and empirical research also discussed problems with moral hazards at home by receiving remittances. [1]

\section{Declaration of Problem}

One of the reasons why the remittance study is done is to make clearer the identification of how remittances affect the reports and publications made by the Kosovo Statistical Agency, the Central Bank of Kosovo etc. It has been seen that there is still room for detailed statistical analysis that would be even more useful to have a clearer picture of the interconnection that would affect the decision-making process. It is very important to know and explore how the future years in Kosovo will be. In addition to Kosovo, the research is also based on data released by the World Bank on remittances to other Balkan countries.

\section{Methodology}

As a first step in the application of methodology in the field of results, it is the calculation of how many percent of remittances in Kosovo are part of Gross Producer Output, and this calculation has been achieved by collecting the remittances values from 2009 to 2016, and divided by the amount of Gross Domestic Product in the same period. On the other hand, with regard to participation expressed in percentage, the participation of each of the Balkan countries for the period 2009 to 2016 will be used as follows: To collect all remittances for each country separately, the sum of all countries, and the sum of each country, is divided by the total amount of remittances in the Balkans. In addition to forecasting interest rates through moving and effective seasonal averages, the application of linear regression is also applied, where according to the need of calculations, apply regression between only two variables, as well as the regression between two ore more many variables.

Presentation and analysis of results

This chapter presents detailed discussions on the level of remittances in Kosovo, Albania and Macedonia. This is because there have been no access to data from other Balkan countries. Comparison will be made between Balkan and Kosovo countries.

\section{Correlation and Regression}

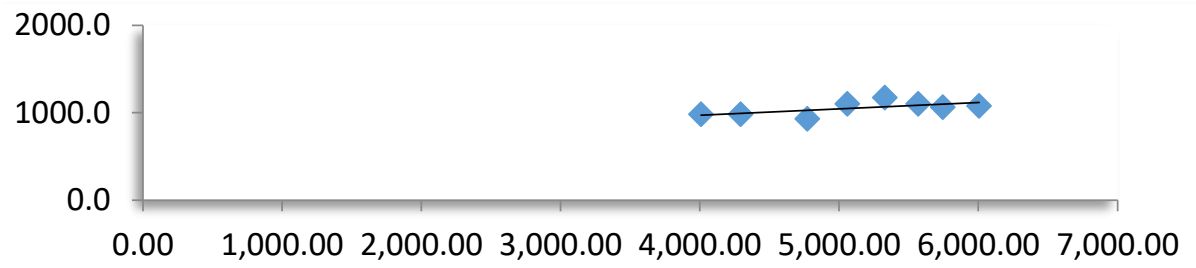

Figure 1. Correlation between Gross Domestic Product and Remittances. Author's Calculations According to Figure 1, we can see that Gross Domestic Product and remittances have a postitive but not strong correlation. For any increase in the level of remittances, it is expressed as Gross Domestic Product growth for 63.25 percent and vice versa. 
Table 1. Correlation between different variables

\begin{tabular}{|c|c|c|c|c|c|c|c|}
\hline & $\begin{array}{l}\text { GDP } \\
(\mathrm{MIL} €)\end{array}$ & $\begin{array}{l}\text { Balance of } \\
\text { payments }\end{array}$ & $\begin{array}{l}\text { Remittance } \\
\mathrm{s}\end{array}$ & $\begin{array}{c}\text { Total } \\
\text { amount of } \\
\text { deposits }\end{array}$ & $\begin{array}{l}\text { Ni/Deposit } \\
\text { s }\end{array}$ & $\begin{array}{l}\text { Investments } \\
(\text { MIL } €)\end{array}$ & $\begin{array}{c}\text { Direct } \\
\text { Foreign } \\
\text { Investmen } \\
\text { ts (MIL€) }\end{array}$ \\
\hline GDP (MIL $€$ ) & 1 & & & & & & \\
\hline $\begin{array}{l}\text { Balace of } \\
\text { Payments }\end{array}$ & $\begin{array}{r}- \\
0.03595404 \\
4\end{array}$ & 1 & & & & & \\
\hline Remittances & $\begin{array}{r}0.63256524 \\
3 \\
\end{array}$ & $\begin{array}{r}0.72638793 \\
2 \\
\end{array}$ & 1 & & & & \\
\hline $\begin{array}{l}\text { Total amount } \\
\text { of deposits }\end{array}$ & $\begin{array}{r}0.98114738 \\
3 \\
\end{array}$ & $\begin{array}{r}- \\
0.17466730 \\
4\end{array}$ & $\begin{array}{r}0.52330083 \\
3 \\
\end{array}$ & 1 & & & \\
\hline Ni/ Deposits & $\begin{array}{r}- \\
0.88053277 \\
8 \\
\end{array}$ & $\begin{array}{r}0.29459659 \\
7 \\
\end{array}$ & -0.3617229 & $\begin{array}{r}- \\
0.85556132 \\
3 \\
\end{array}$ & 1 & & \\
\hline $\begin{array}{l}\text { Investments } \\
\text { (MIL€) }\end{array}$ & 0.66489913 & $\begin{array}{r}- \\
0.57580639 \\
6 \\
\end{array}$ & 0.00367402 & $\begin{array}{r}0.76983507 \\
5 \\
\end{array}$ & $\begin{array}{r}- \\
0.5547368\end{array}$ & 1 & \\
\hline $\begin{array}{l}\text { Direct } \\
\text { Foreign } \\
\text { Investments } \\
\text { (MIL€) }\end{array}$ & $\begin{array}{r}- \\
0.54953711 \\
8\end{array}$ & $\begin{array}{r}- \\
0.39935667 \\
3\end{array}$ & $\begin{array}{r}- \\
0.67340687\end{array}$ & -0.4599969 & $\begin{array}{r}0.5192310 \\
9\end{array}$ & $\begin{array}{c}0.15897479 \\
2\end{array}$ & 1 \\
\hline
\end{tabular}

Source: (Central Bank of Kosovo n d), (Statistical Agency of Kosovo n d), Author's calculations

According to the correlaction table, we can notice that the highest correlaction remittances have the variable called "Balance of Payments", meaning that if Remittances increase for one euro, the balance of payments increases for 72.63 cents and vice versa. A positive correlation was also shown between remittances and total deposits, which showed a correlation of 52.33 percent, which indicates that for any increase in remittances, deposit growth is influenced by 52.33 percent and vice versa, buth with regard to the interest rate on deposits, we have a low negative correaltion of 3.67 percent, which can be said that the deposid interest rate does not have any impact which could have an effect on their decision-making about depositing their assets. [2]

Grecce, $6.85 \%$

Kosovo, $7.24 \%$

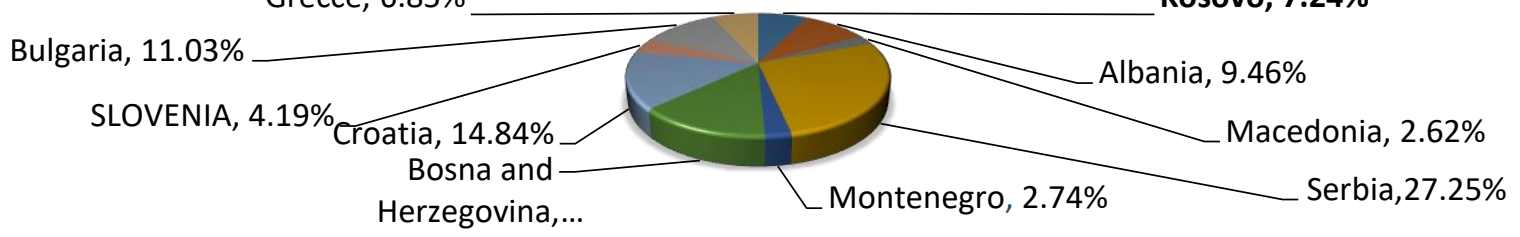

Figure 2. Percentage participation of Balkan countries. Source. (World Bank n.D), Author's calculations.

As can be seen in the figure above, the country that shows the highest percentage of remittances is Serbia, followed by Croatia, Bosnia and Slovenia. Kosovo in this area marks a percentage of 7.24 percent, a very low percentage which is conditional on the number of a country's population and the percentage of emigrants, and Kosovo in known to have a small population. In the previous analysis, we saw the percentage of Kosovo participating in the Gross Domestic Product. 


\section{$1700.0\urcorner$ Remittances in Kosovo}

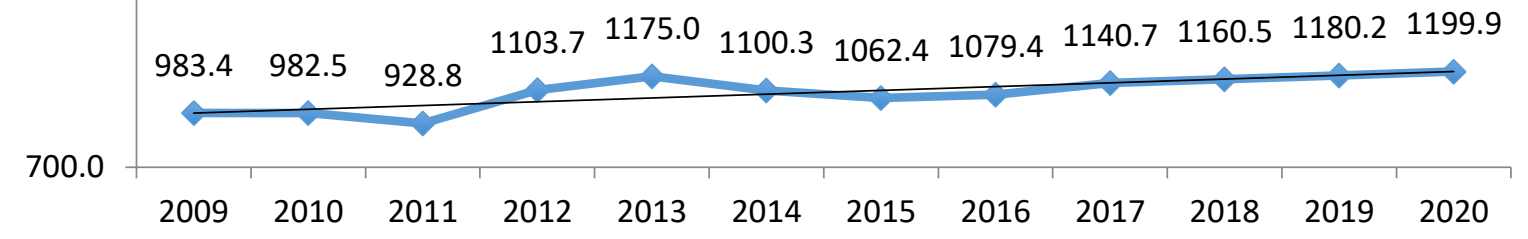

Figure 3. Remittances foreacast in Kosovo by 2020. Source: (World Bank n.D), Author's calculations.

As we can see in the figure above, remittances in Kosovo are projected to increase. In 2009, remittances totaled 983 billion euros. The largest increase we had in 2013, where remittances amounted to 1 billion and 175 million euros. This level is projected to be passed in 2019 and 2020, with remittances reaching 1 billion 180 million for 2019 and 1 billion of 199 million for 2020. In addition to the forecast using the linear regression method, in which case as independent variables are used the years (2009 to 2016) and remittances of the same period are used as a dependent variable. In the next case an assumption will be shown. If we take as an example the foressen remittances, how much will the Gross Domestic Product value reach, then as an independent variable the anticipated remittances will be taken (from 2017 to 2020), and as the dependent Gross Domestic Product variable.

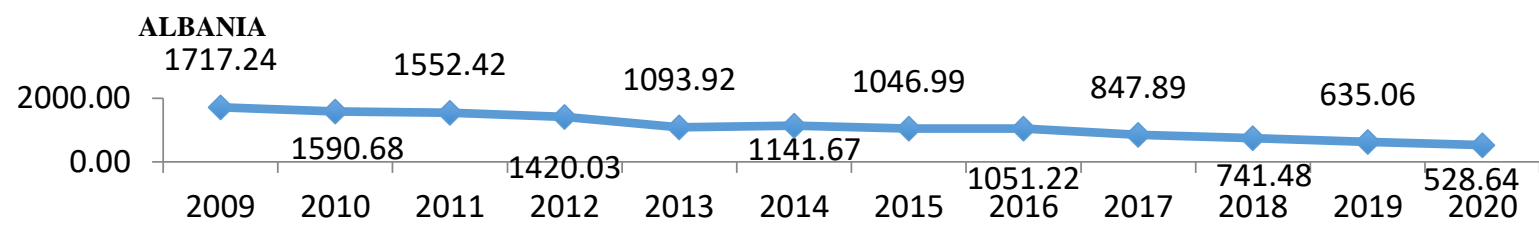

Figure 4. Remittances forecast in Albania by 2020.

Source: (World Bank, d.d), Author's calculations

As we can see in Figure 9, remittances in Albania are downward. At the beginning of the period, remittances in Albania amounted to $\$ 1.7$ billion and it is predicted that by 2020 there will be a decline of over 50 percent of 2009 value.

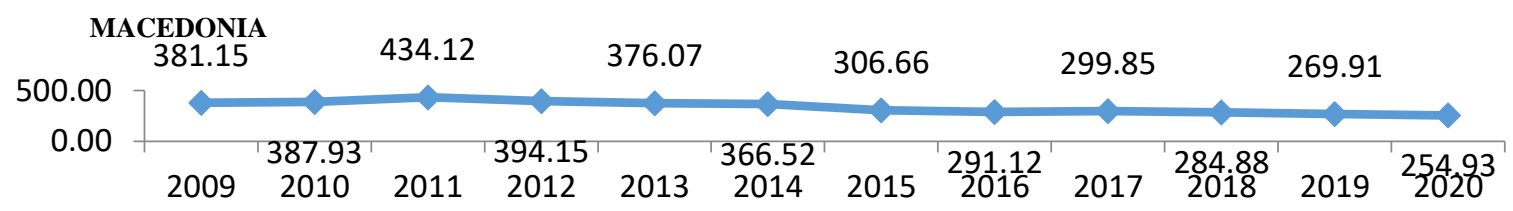

Figure 5. Remittances forecast in Macedonia by 2020.

Burimi: (World Bank n.d), Author's calculations.

Macedonia is also expected to experience a decline in remittances. However, this decline is not predicted to have an even bigger impact, as there is no big difference. At the beginning of 2009 , Macedonia had a value of $\$ 381$ million worth of remittances and is predicted to fall by $\$ 254.9$ million in 2020. 


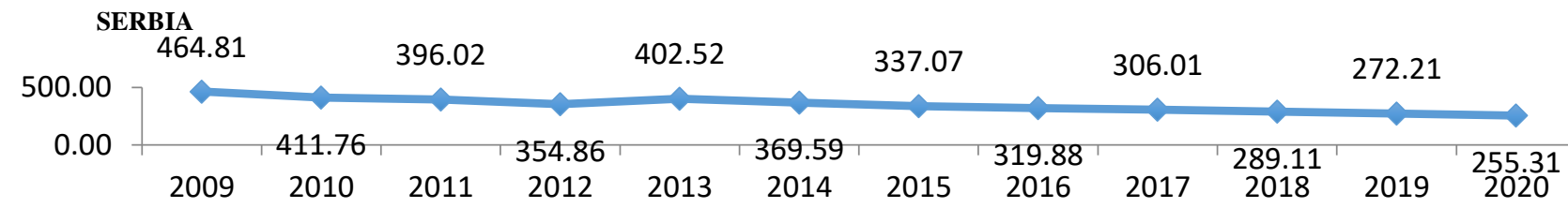

Figure 6. Remittances forecast in Serbia by 2020 Remittances forecast in Serbia by 2020. Soruce: (World Bank n.D), Author's calculations.

The value of remittances in Serbia is similar to those in Macedonia, only having somewhat higher values. At the beginning of 2009 , Serbia had remittances worth $\$ 464.8$ million, and is expected to drop to $\$ 255.3$ million.

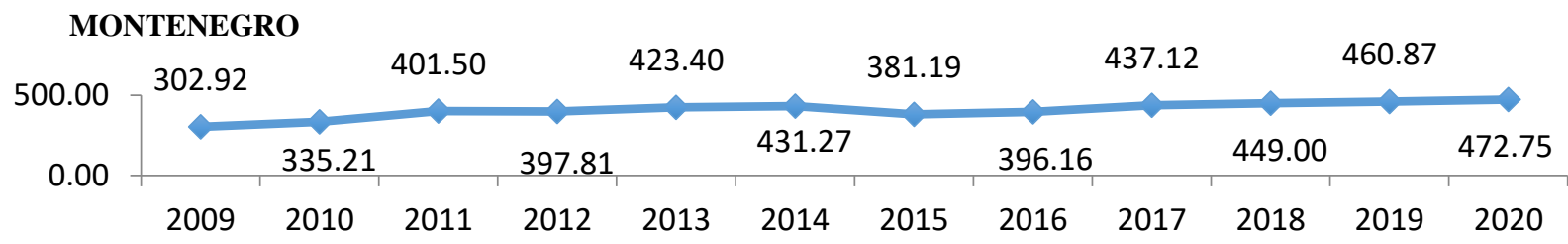

Figure 7. Remittances forecast in Montenegro by 2020.

Sorce: (World Bank n.D), Author's calculations.

As far as Montenegro is concerned, it is seen in the figure that there is expected to be an increase of remittances in the years to come. At the beginning of 2009, remittances amounted to $\$ 302.9$ million, and is projected to reach

BOSNA AND HERZEGOVINA

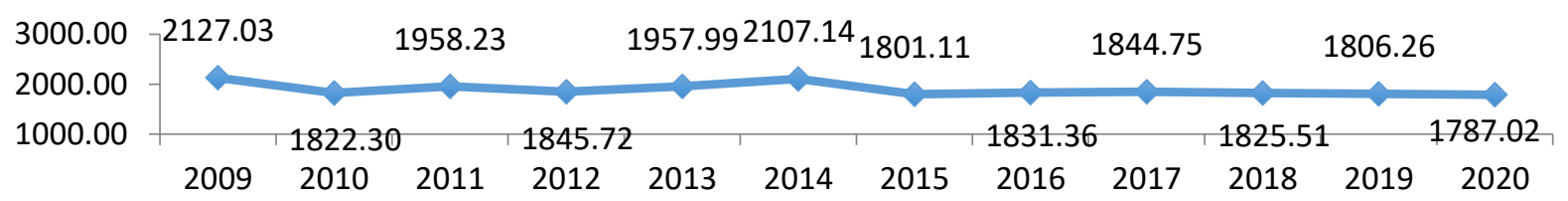

Figure 8. Remittances forecast in Bosnia and Herzegovina by 2020.

Source: (World Bank d.d), Author's calculations

Figure 8 shows remittances for Bosnia and Herzegovina, which unlike other Balkan countries, is seen to have had the largest movements during 2009 to 2015 . The remittances value in 2009 was $\$ 2.12$ billion, but it is expected that to fall to $\$ 1.78$ billion in 2020 .

\section{CROATIA}

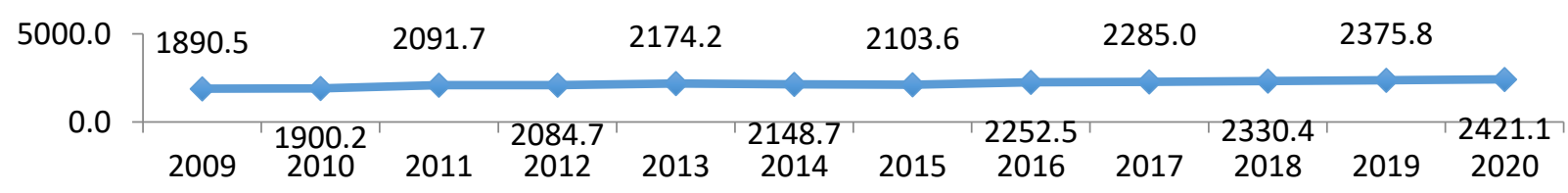

Figure 9. Forecast of remittances in Croatia by 2020.

Source: (World Bank, n,d), Author's calculations. 
Also, Croatia is seen to be distinct from other Balkan countries, because of the fact that there are no major differences of multiple oscillations of remittances over the years. Remittances in Croatia are expected to grow by $\$ 1.89$ billion, which were 2009 values up to 2.42 billion for

\section{SLOVENIA}

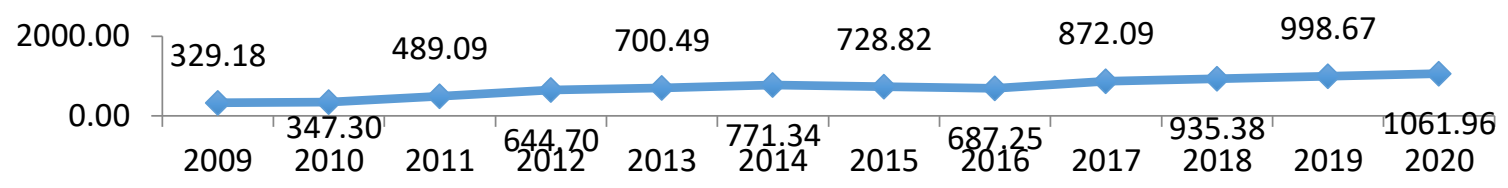

2020.Figure 10. Remittances forecast in Slovenia by 2020.

Source: (World Bank, n.d), Author's calculations

In Slovenia we notice that there will be a continuous rise in the level of remittances, with some downturns over the years. At the beginning of the period, remittances amounted to $\$ 329.2$ million, while forecasted to reach $\$ 1.06$ billion in 2020 .

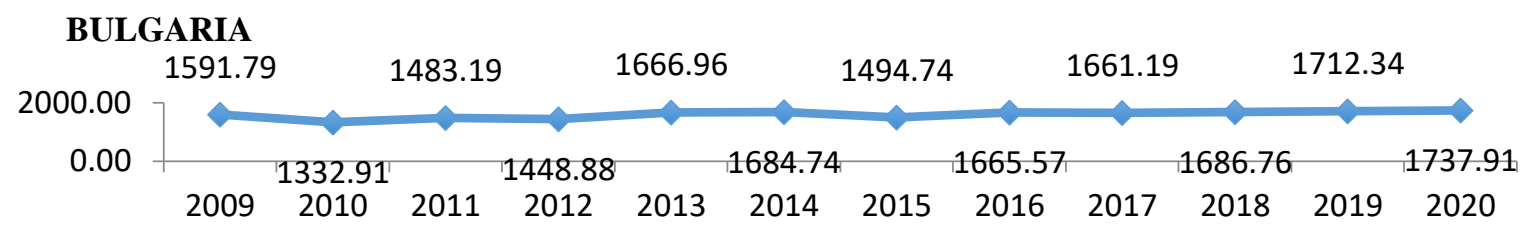

Figure 11. Forecast of remittances in Bulgaria by 2020.

Source: (World Bank, n.d), Author's calculations.

Looking at the last place in which the forecast is made, we note that Bulgaria presents high levels of remittances. Over the next few years, it has been characterized by growth, and is projected to have further growth. At the beginning of 2009, remittances totaled $\$ 1.57$ billion and are expected to grow to $\$ 1.73$ billion in 2020 .

\section{Forecast by seasonal effects and moving averages}

This method applies only to the country of Kosovo, because the basic condition for applying this method is that the data are in time series, monthly or quartely, where only data for the Kosovo country are found in the period quarterly.

\section{Forecasting remittances through moving averages- collecting model}

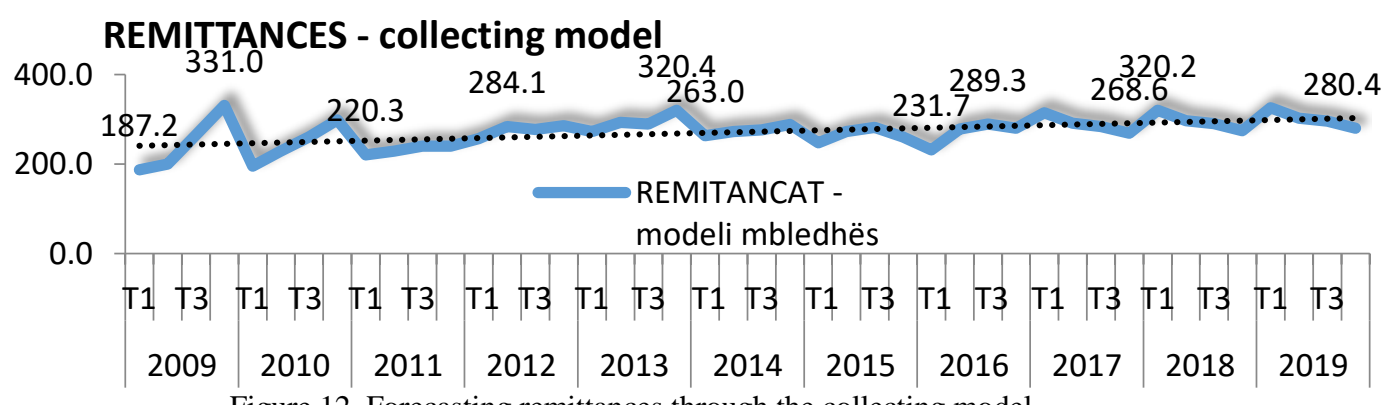

Figure 12. Forecasting remittances through the collecting model

Author's Calculations 


\section{Forecast of remittances through seasonal effects- multiplication model}

\section{REMITTANCES - multiplication model}

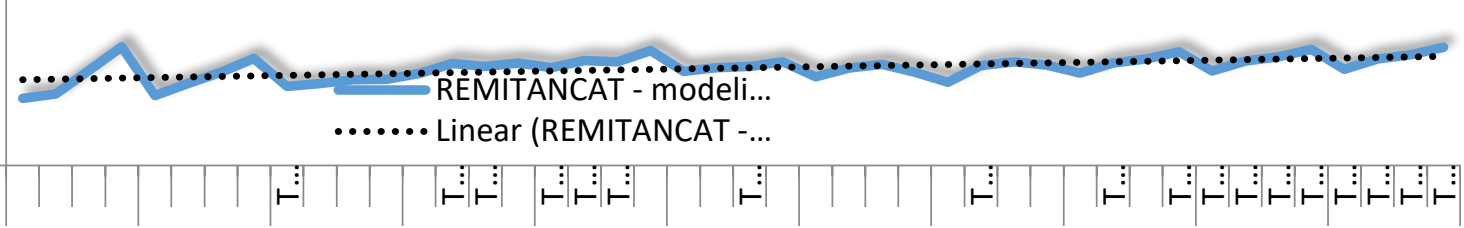

Figure 13. Forecast of remittances through seasonal effects- multiplication model

Author's Calculations

\section{Discussions and Conclusions}

Based on the results achieved, we note that remittances in Kosovo have a very high share in the economic development of Gross Domestic Product. Remittances account for a total of 20.64 percent of Gross Domestic Product. After Kosovo is ranked Bosnia and Herzegovina with about 11 percent, and Albania with 10.8 percent, while Greece's lowest share with 0.35 percent. Particular importance is given to Kosovo, which has as a result that the percentage of remittance participation has a high positive correlation with the percentage of participation in Serbia, whereas the high negative correlaction with Montenegro's. In general, we can say that in most of the Balkan countries, remittances and their trend are projected to decrease, and according to the trend application, we can see that remittances in Kosovo tend to increase. Regarding the parabolic trend, we can see that we have a constrant growth, then at the end of the period we have a decrease, and this is generally due to the applied method, while remittances generally have an upward trend. Over the next few years, it has been characterized by growth, and is projected to have further growth. At the beginning of 2009 , remittances amounted to $\$ 1.57$ billion, rising to $\$ 1.73$ billion in 2020, and also having a low impact on economic growth of 2.9 percent. As far as Greece is concerned the forecast for this country has not been possible, since it has had extremely high significange and results have been rendered meaningless. As a result in the Balkan countries, the average value of all countries in 2009 was 1.6 billion, in 2016 it was 1.26 billion, and by 2020 it is projected to drop to $\$ 1.11$ billion, a decline that will be highly in favor for Balkan countries.

\section{REFERENCES}

1. DIETZ, B., 2010. Migration and Remittances in Macedonia: A Review. OSTEUROPAINSTITUT REGENSBURG.

2. Agjensia Statistikore e Kosovës, n.d. Agjensia Statistikore e Kosovës. 